Hispania, 2021, vol. LXXXI, n. . 269, septiembre-diciembre, págs. 621-650 ISSN: 0018-2141, e-ISSN: 1988-8368, https://doi.org/10.3989/hispania.2021.015

\title{
Allegretto Allegretti: un diplomático de Ragusa al servicio de los Habsburgo*
}

\section{Miguel Conde-Pazos ${ }^{1}$}

Universidad Alfonso X el Sabio / IULCE, de la UAM

mcondpaz@uax.es

RESUMEN: Originario de la república de Ragusa, Allegretto Allegretti fue uno de los principales agentes con los que la Casa de Austria contó a mediados del siglo XVII. Este eclesiástico realizó numerosas misiones para las dos ramas de la dinastía - en Varsovia, Constantinopla y Moscú, entre otros lugares-, distinguiéndose por sus dotes idiomáticas. En Viena formó parte del entorno de la embajada española, sirviendo a la emperatriz María Ana, así como a los sucesivos embajadores entre las décadas de 1630 y 1650. Este artículo reconstruye una parte de su vida, centrándonos en sus servicios a la rama hispana de la dinastía y su carrera cortesana. Una biografía que refleja las grandes trasformaciones que se produjeron durante aquellas décadas en la Europa central y suroriental, sobre todo en sus relaciones con Madrid. Pero también, una vida que plasma los cambios en los equilibrios dentro de la propia Casa de Austria, en los que la Monarquía Hispana perdió una parte importante de su influencia en la corte de Viena.

Palabras clave: diplomacia; Casa de Austria; Dubrovnik; PoloniaLituania; Moscovia; Imperio Otomano; Balcanes.

\section{Allegretto Allegretti: a diplomat from Ragusa who served the Habsburgs}

ABSTRACT: Originally from the Republic of Ragusa, Allegretto Allegretti was one of the main agents of the House of Austria in the mid-seventeenth century. An

* Para este trabajo se han utilizado documentos del Archivo General de Simancas, Simancas, Valladolid, Sección Estado (AGS, EST); Archivo Histórico Nacional, Madrid, secciones Estado (AHN, EST); Biblioteca Nacional de Madrid (BNM); Real Academia de la Historia, Madrid (RAH); y Haus-, Hof- und Staatsarchiv de Viena (HHStA).

${ }^{1}$ ORCID iD: https://orcid.org/0000-0001-9989-9607

Copyright: (C) 2021 CSIC. Este es un artículo de acceso abierto distribuido bajo los términos de una licencia de uso y distribución Creative Commons Reconocimiento 4.0 Internacional (CC-BY 4.0) 
ecclesiastic who stood out for his linguistic abilities, he undertook numerous diplomatic missions for the two branches of the dynasty, including in Warsaw, Constantinople and Moscow. In Vienna he was part of the circle of the Spanish embassy, serving the Empress Maria Anna, as well as successive ambassadors in the 1630s and 1650s. This article reconstructs a part of his life, focusing on his services to the Hispanic branch of the dynasty and his court career. The biography reflects the great transformations that took place during those decades in Central and South-eastern Europe, especially in its relationship with Madrid, as well as the changes in balance within the House of Austria, when the Hispanic Monarchy lost an important part of its influence in the court of Vienna.

Key words: Diplomacy; House of Austria; Dubrovnik; Polish-Lithuanian Commonwealth; Muscovy; Ottoman Empire; Balkans.

CÓMO CITAR ESTE ARTÍCULO / CITATION: Conde-Pazos, Miguel, «Allegretto Allegretti: un diplomático de Ragusa al servicio de los Habsburgo», Hispania, 81/269 (Madrid, 2021): 621-650. https://doi.org/10.3989/hispania.2021.015.

La figura de Allegretto Allegretti (†1658) es sobre todo conocida por su papel al frente de la embajada imperial en Moscovia del año 1655 y su labor de mediación en la paz de Vilna del año siguiente ${ }^{2}$. Últimamente también se ha recuperado su actuación como enviado de Felipe IV a Constantinopla en el año 1650, una misión que respondió a la llegada de un embajador otomano a Madrid durante el verano anterior ${ }^{3}$. Sin embargo, poco más se sabe del resto de su vida, además de que era eclesiástico y originario de la ciudad de Ragusa - Dubrovnik-. Y todo ello, a pesar del notable papel que desempeñó al servicio de la Casa de Austria durante tres décadas como cortesano y diplomático. Allegretti fue un buen ejemplo de cómo la política de colaboración dinástica practicada por Madrid y Viena durante la primera mitad del siglo XVII propició la complementariedad de lealtades, siendo el raguseo un instrumento más, como agente, de su ejecución. Instalado en Viena, Allegretti se convirtió en un colaborador habitual de la embajada española, para lo cual realizó numerosas misiones en el exterior. Al mismo tiempo se erigió como una figura destacada dentro de la corte imperial, donde supo ganarse la confianza del entorno de Fernando III y, particularmente, de su esposa, la emperatriz María Ana. A ello hay que sumar su labor en beneficio de la Iglesia de Roma, así como una postura favorable hacia su Ragusa natal, pues

2 PRIBRAM, 72/2 (Viena, 1889): 415-480. KONRÁDOVÁ y SMIŠEK, 19 (Pardubice, 2016): 45-73.

${ }_{3}$ CONDE PAZOS, 3, (Madrid, 2011b): 10-17. QUILES ALBERO, 44 (Granada, 2018): 381-406. 
nunca rompió del todo con sus orígenes y, menos aún, con su familia, combinando en su persona distintas lealtades.

Este trabajo pretende cubrir el vacío que rodea la mayor parte de su vida, utilizando para ello esencialmente fuentes primarias. Y dado que la mayoría de estas son de origen hispano, nos centramos en sus relaciones con la corte de Madrid, sin dejar de lado el resto de sus cometidos, con el objetivo de poder realizar una biografía lo más completa posible. Con ello queremos presentar un cursus honorum paradigmático: el de un ministro foráneo que logró integrarse y ascender dentro del entramado de la Casa de Austria simultaneando sus servicios a las dos ramas, en un contexto en el que el equilibrio de fuerzas en el continente, pero también dentro de la propia familia austriaca, estaba cambiando y se producía una apertura hacia el exterior, especializándose Allegretti en misiones en lugares considerados periféricos, como eran el Imperio Otomano y Moscovia.

\section{LOS ORÍGENES: RAGUSA}

Los primeros años de la vida de Allegretti son los que mantienen más sombras. Originario de la república de Ragusa, desconocemos el año exacto de su nacimiento, aunque por las descripciones de las fuentes - que descartan su juventud para la década de 1630 — y la fecha de su muerte — 1658_, suponemos que debió ser durante las dos últimas décadas del siglo XVI. Tampoco conocemos el nombre exacto de sus padres, si bien sabemos, por el primer memorial que Allegretto presentó en Madrid - 1628 - , que formaba parte de un linaje con un largo historial al servicio de la Casa de Austria. En concreto, su abuelo había servido durante años a Carlos V en sus acciones en el Mediterráneo oriental, acompañado de otros seis hermanos, algunos de los cuales cayeron cautivos de los turcos y fueron desollados ${ }^{4}$. Esta información fue confirmada en su momento por la corte española, convirtiéndose en el principal mérito que Allegretto pudo esgrimir de cara a sus primeras pretensiones en Madrid. Sin embargo, no es fácil identificar a estos ancestros pues, como veremos a continuación, la relación con Ragusa siempre estuvo sujeta a condicionantes de carácter secreto ${ }^{5}$. Sí que encontramos a otros miembros de la familia Allegretti sirviendo a la Monarquía en años posteriores, como son el caso de un

${ }^{4}$ Felipe IV al duque de Alcalá, Madrid, 8-X-1629, AHN, EST, 1. 319, f. 313. Consejo de Estado, 16-VIII-1642, AGS, EST, 2805.

${ }^{5}$ Emilio Sola identifica para el año 1532 a Stefano de Alegreto de Canal, criado de Machael Bousignola - referencia probable a uno de los hermanos Bucignolo, promotores de los Austria entre el patriciado de Ragusa-, quien pudo ser uno de los ancestros de los que Allegretti habló, SOLA, 2009. 
capitán de nao que transportó armas de Italia a Alicante para Felipe II en $1569^{6}$, o de Jorge de Allegretti, quien, en 1573, se hizo sospechoso de ser un agente doble ${ }^{7}$. En fechas más recientes hallamos al capitán Blas de Allegretti, quien en 1618 realizó una misión para el virrey de Nápoles — probablemente en el Mediterráneo oriental - por la cual percibió 50 escudos de los gastos secretos ${ }^{8}$; y a los hermanos Nicolás y Jerónimo de Masebradi y Allegretti, los cuales prestaron valiosos servicios para la Monarquía y pretendieron un hábito de la Orden de Santiago en los años 1633 y 1634, respectivamente 9 . También encontramos a otros miembros de la familia al servicio de Roma. Tal es el caso de Francesco Allegretti, quien jugó un papel importante como agente de Clemente VIII en la toma de Kliss a finales del siglo XVI; y al clérigo Ignazio Allegretti, uno de los puntales de la actividad misional del papado en Hungría ${ }^{10}$. Sin embargo, no podemos establecer una filiación segura para nuestro Allegretto, pues este solo habló en sus cartas de tres familiares directos, sin especificar nunca su nombre: dos hermanas huérfanas, a las que dijo mantener, y un primo, en quien trató de delegar una merced que Felipe IV le hizo en $1650^{11}$. En cualquier caso, estamos tratando a un linaje numeroso, dedicado fundamentalmente al comercio, la mar y los seguros mercantiles ${ }^{12}$. Según Filiberto Campanile - 1618 - , el origen de los Allegretti estaba en Bosnia, de donde habían tenido que huir tras la conquista otomana - siglo XIV—, recalando en Ragusa. Más adelante, una parte de la familia se trasladó a Italia, a la Romaña y Nápoles, donde se hicieron señores de Mirabello, mientras que el resto permaneció en Ragusa, siendo Allegretto de esta última rama ${ }^{13}$.

No hay duda de que los orígenes raguseos de Allegretti marcaron buena parte de su biografía posterior. Situada en la costa del Adriático, la república de San Blas fue un espacio de confluencia entre el mundo otomano y los poderes

${ }^{6}$ VARGAS-HIDALGO, 2003: 590-600.

7 Carta de Luis Portillo a Felipe II, Ragusa, 13-II-1573, AGS, EST, 1332, f. 170.

${ }^{8}$ Consulta resuelta el 22-V-1618, AHN, EST, 1. 371. Felipe IV al virrey de Nápoles, 27-VII1621, AHN, EST, 1. 318.

9 AHN, Órdenes Militares, Caballeros, Santiago, exp. 4999 y 5000.

${ }_{10}$ MOLNÁR, 11 (Roma, 2012): 47-68.

${ }^{11}$ Consejo de Estado, 7-V-1646, AGS, EST, 2810. Consejo de Estado, 10-IX-1651, AGS, EST, 3738. Tampoco descartamos un cambio de nombre acercándolo al apellido, una práctica que hemos observado en otros clérigos raguseos, como en el caso de Damiano de Damianis, capellán de la armada en Nápoles, Felipe IV al virrey de Nápoles, Valsaín, 23-X-1621, AHN, EST, 1. 147.

12 TENENTI y TENENTI, 1985. Una búsqueda en los catálogos de los fondos documentales de Dubrovnik revela la existencia de otros miembros de la familia, por ejemplo en los testamentos de los fondos notariales, como es el caso de Simón y Nicolás Allegretti — siglo XV— o Allegretti de Ruschi — siglo XVI—, LUME, 1977: 152-154; sin embargo, como apunta este autor, hay que tener en cuenta que una parte de la documentación sufrió las consecuencias del terremoto de 1667.

13 CAMPANILE, 1680: 409-411. 
católicos. Vasalla de los sultanes desde el siglo XV, al mismo tiempo que católica, Ragusa era tanto para Roma como para Madrid la principal vía de acceso a los Balcanes, así como uno de los puntos neurálgicos de sus redes de información, obteniéndose allí una parte importante de los avisos que llegaban sobre Constantinopla y el Levante oriental. Un papel que también se daba a la inversa, funcionando para el Imperio Otomano como una auténtica ventana hacia Occidente. Esto marcó el carácter de la ciudad, que siempre estuvo habitada por multitud de espías y residentes extranjeros. En Ragusa se negociaba la liberación de cristianos cautivos, se establecían contactos con los pueblos del interior y eran monitorizados los movimientos de la flota otomana, lo que convirtió a la urbe en un actor importante en la estrategia general de la Monarquía Católica en el Mediterráneo oriental ${ }^{14}$. La república, por su parte, siempre trató de mantener una estrecha relación con el reino de Nápoles. Amenazada su independencia por Venecia, casi tanto como por los propios turcos, sus autoridades tendieron a buscar la protección de la corte napolitana y, a través de esta, de Madrid. A ello había que sumar la gran dependencia que, para su sustento, tenía la ciudad de las importaciones de cereal italiano, lo que llevó a Ragusa a firmar una serie de acuerdos comerciales y de protección con Carlos V y Felipe II —en 1534 y 1561 respectivamente-, así como al establecimiento de unos lazos que, con el tiempo, llevaron a muchos raguseos a servir en las flotas y las tropas de la Monarquía ${ }^{15}$. Conocida es la presencia de multitud de sus marinos en la Armada Invencible y durante los años siguientes hubo una serie de casos particulares muy a destacar, como los de Vice Bune (1559-1612) y las familias Ohmucevic y Olistit ${ }^{16}$. Estos lazos se intensificaron durante las primeras décadas del siglo XVII, coincidiendo con la juventud de Allegretto, a raíz de la activa política desarrollada en el Adriático por los sucesivos virreyes de Nápoles ${ }^{17}$. Unos años en los que, según Zdenko Zlatar, surgió dentro de la elite gobernante de Ragusa un poderoso grupo de tendencias anti-otomanas, proclive a los proyectos de Roma y Madrid en la zona. Un grupo fuertemente influenciado por la Compañía de Jesús, que se instaló en la república a principios de siglo ${ }^{18}$.

Es probable que todos estos elementos fueran determinantes en la formación de Allegretto y su decisión de servir a Felipe IV, lo que, por otra parte, no hizo sino continuar con la tradición familiar. Más aún, algunas fuentes parecen situar a Allegretto dentro de la órbita jesuita, por lo que pudo estar vinculado a las ideas de Aleksandar Komulović (1548-1608), uno de los introductores de la

14 BUNES IBARRA, 2010: 223-240.

15 D'ATRI, 14 (Dubrovnik, 2010): 71-98. ŠUNDRICA, 4 (Dubrovnik, 2000): 7-79.

16 VILLARI, 1904: 306-315. KOSTIĆ, 3 (Belgrado, 1972): 195-235.

17 GONZÁLEZ CUERVA, 2008: 1447-1471. FLORISTAN IMÍZCOZ, 1988.

18 ZLATAR, 1992a. 
compañía en Ragusa, quien propugnó en sus escritos la unidad de los poderes eslavos contra el turco bajo el liderazgo católico - lo que algunos han querido ver como la génesis del paneslavismo-. Komulovic realizó varias misiones en Polonia y Moscovia, y no es descartable que sus ideas terminaran afectando en la carrera de nuestro diplomático, si bien este siempre supeditó su labor a los intereses de la familia austriaca ${ }^{19}$.

La primera mención que tenemos de Allegretti en las fuentes data de 1627. Cinco años antes, en 1622, había llegado a Madrid una embajada proveniente de la república, liderada por el noble Marino Gradi, la cual tenía como objetivo renovar los antiguos lazos de protección y comercio firmados por Carlos $\mathrm{V}$ y Felipe II $^{20}$. Para entonces la Guerra de los Treinta Años ya había estallado, y tanto el Adriático como el Mediterráneo oriental habían quedado desplazados dentro de las prioridades exteriores de la corona española. Entre los objetivos de Gradi estaba que la Monarquía volviera a tener a un agente fijo en aquella ciudad para que se hiciera cargo de los avisos y los asuntos comerciales, como ya había ocurrido durante los años previos desde el siglo anterior ${ }^{21}$. Con el fin de dar fuerza a su negociación, Gradi introdujo la posibilidad de realizar dos levas en la zona, una de 400 hombres entre sus marineros y otra de 2.000 infantes provenientes de Albania, de la que perfectamente podía hacerse cargo dicho agente. Unas propuestas, todas ellas, que fueron bien recibidas en la corte madrileña que, eso sí, prefirió delegar la concreción de los acuerdos y la leva en la corte de Nápoles, por ser ésta a la que afectaba más directamente. También delegó la designación del agente, cuya recuperación se juzgó muy conveniente en Madrid ${ }^{22}$.

La llegada de Allegretti a la corte española se produjo cinco años más tarde, teniendo como objetivo el hacerse con la agencia de Ragusa. Ya hemos visto anteriormente como los principales méritos que este esgrimió entonces fueron los servicios prestados por sus antepasados, así como «otro tipo de razones» que no fueron especificadas ${ }^{23}$. No es descartable que Allegretti hubiera realizado labores de información previas para la Monarquía. Sin embargo, para entonces se había establecido un sistema de pseudónimos en los avisos y omisiones en las comunicaciones con Ragusa que tenía como objetivo garantizar la seguridad de las redes en el Mediterráneo oriental y que hoy en día hace muy difícil la identificación de su autoría ${ }^{24}$. En cualquier caso, Allegretti pronto vio frustradas sus aspiraciones, ya que el puesto no estaba vacante, por lo que se tuvo que conformar con una recomendación del rey para el futuro. Eso sí,

${ }^{19}$ HARRIS, 2006: 234-237.

${ }^{20}$ La república de Ragusa a Felipe IV, 4-IV-1622, AGS, EST, 1884, f. 172.

21 POLIĆ, 2000.

${ }^{22}$ Felipe IV al duque de Alba, Madrid, 30-XII-1622, AGS, EST, 1884, f. 310.

${ }^{23}$ Felipe IV al virrey de Nápoles, Madrid, 8-X-1629, AHN, EST, 1. 319, f. 313.

24 PETITJEAN, 2013: 83-106. 
durante los meses que permaneció en la corte logró que su caso fuera estudiado, aprobándose para él una pensión de 150 ducados en 1628 proveniente de las rentas eclesiásticas de Italia ${ }^{25}$. Una merced que, como otras tantas que recibiría en el futuro, no llegó a gozar hasta muchos años más tarde.

\section{Viena, Cracovia y Silesia (1630-1638)}

La siguiente referencia que tenemos de Allegretti data del año 1633 en Cracovia, cuando este ya estaba integrado en el servicio de la embajada española en Viena. Desconocemos la vía concreta en la que se produjo su traslado a la zona. Según G. Gualdo Priorato - 1669_, viajó al Imperio como limosnero de la reina María Ana, si bien no hemos hallado un registro documental que lo acredite $^{26}$. Otra posibilidad es que llegara en alguno de los muchos cambios que durante esos años se produjeron en la embajada de Alemania ${ }^{27}$. La década previa de 1620 había estado marcada por el liderazgo de los sucesivos embajadores españoles, que habían acumulado tanto poder que terminaron causando cierto malestar. Por ello, a finales de la década se intentó establecer desde Madrid un sistema colegial más equilibrado dentro de la embajada, que reforzara la labor de la reina de Hungría como principal mediadora entre las dos familias. Un nuevo orden de cosas para el que Olivares quiso el envío de gentes «doctas y religiosas»». Otra posibilidad es que Allegretto pasara antes por Italia, por alguna de las embajadas o una corte virreinal. Al fin y al cabo, el conde de Roca, nombrado en 1630 embajador en Venecia, tuvo entre sus cometidos el obtener avisos del Mediterráneo oriental, mientras que el marqués de Castañeda, con el que posteriormente Allegretto estuvo tan ligado, fue embajador en Génova antes de pasar a Viena. Por otra parte, la corte de Madrid siguió estando interesada en hacerse con los servicios de los barcos y marineros raguseos, como prueba un nuevo proyecto de reclutamiento planteado en $1632^{28}$. En cuanto a los motivos que llevaron a Allegretti a la corte imperial, pudo deberse a su condición eclesiástica, si bien sus responsabilidades posteriores nos hacen pensar que estuvo más bien relacionado con su dominio de los idiomas, que incluyeron el español, el italiano, el latín y el «ilirio». La inclusión de esta última lengua, hablada por las gentes de Ragusa, pudo ser clave, pues entroncaba directamente con el resto de las hablas del mundo eslavo, lo que brindaba a la embajada una mejor aproximación a las gentes de los Balcanes y los reinos

${ }^{25}$ Consejo de Estado, 16-VIII-1642, AGS, EST, 2805.

${ }^{26}$ GUALDO PRIORATO, 1669, vol. I: 592. LABRADOR ARROYO, 2011, vol. 2: 801-836.

${ }^{27}$ MAREK, 2018, vol. 1: 117-210. NEGREDO DEL CERRO, 25/251 (Madrid, 2015): 669-693.

${ }^{28}$ Felipe IV al duque de Cardona, Madrid, 15-VII-1632, AGS, EST, 3445, f. 133. 
del centro y el este de Europa ${ }^{29}$. Este elemento promovió la integración de los raguseos en los aparatos diplomáticos de Roma y Viena durante los siglos XVI y XVII, convirtiéndose en muchos casos en los arquetipos de agentes transculturales y trans-confesionales, dadas sus actividades en el ámbito turco, pero también en el ortodoxo - Ucrania, Moscovia - ${ }^{30}$. En el caso de Allegretti, su paso a la embajada pudo deberse al interés que aún despertaban los Balcanes en Madrid, erigiéndose la corte imperial como un centro de información destacado dentro de las redes de la Monarquía; pero también a la aproximación que desde hacía años se realizaba hacia el reino polaco-lituano, que en el contexto geopolítico de la Guerra de los Treinta Años se convirtió en un aliado muy valioso para la Casa de Austria ${ }^{31}$.

La llegada de Allegretti a Cracovia, de la que antes hacíamos mención, se produjo en 1633, como parte de una embajada protocolaria dirigida por el conde de Siruela para dar la enhorabuena a Ladislao IV por su ascenso al trono. Una representación en la que también estuvo presente el confesor de la reina de Hungría, el capuchino don Diego de Quiroga. El papel que jugó Allegretti en aquella misión fue menor, tratándose en cualquier caso de una embajada de etiqueta, destinada a reforzar la amistad con los Vasa polacos. El viaje, probablemente, sirvió como un primer contacto entre el raguseo y Ladislao IV, monarca que en aquel momento despertaba grandes esperanzas en el mundo eslavocatólico - Ivan Gundulić, compatriota de Allegretti, le situó como el gran paladín anti-turco en su poema Osmán-, así como en la corte de Madrid, dadas sus reivindicaciones sobre el trono sueco y la buena relación que hasta entonces había mantenido con los españoles. Sin embargo, la preocupación de Ladislao en aquel momento no estaba centrada en el conflicto alemán, sino en la frontera del este, que había sido atacada por los moscovitas durante el interregno - Guerra de Smolensko, 1632-1634-. Por ello, el rey apenas permaneció en Cracovia tras su coronación, marchando poco después para unirse a sus ejércitos. Antes de partir, Allegretti tuvo la oportunidad de firmar en el libro de visitas de Adam Kazanowski - camarero real y persona muy cercana a Ladislao-, añadiendo el siguiente aforismo: «Osar morir da la vida $\rangle^{32}$.

En el año 1635, ya en Viena, el raguseo se dedicó a un cometido de una naturaleza muy diferente: la traducción del español al italiano de la obra «Instrucción y obligacion del Christiano fundada en los siente sacramentos de la Iglesia». Un libro escrito por el franciscano descalzo Pedro de Orozco que estaba dirigido al consuelo espiritual de los españoles que habitaban en

29 SOTIROVIĆ, 15 (Vilna, 2014): 175-187.

${ }^{30}$ MIOVIĆ-PERIĆ, 5 (Dubrovnik, 2001). VAN GELDER y KRSTIĆ, 19 (York, 2015): 93-105.

31 SKOWRON, 2013.

32 PRZEZDZIECKI, 128/2 (Madrid, 1948): 509-593. 
Viena. La traducción respondía al pedido del nuncio Malatesta Baglioni para que la obra también pudiera ser leída por los italianos de aquella corte. Dicha labor debió ser muy intensa para Allegretti, pues hablamos de un tratado de más de seiscientas páginas y apenas pasaron dos meses entre la publicación del original y su traducción al italiano, lo que por otra parte demuestra su gran dominio sobre ambos idiomas. El libro también deja algunas pistas sobre la posible filiación de Allegretti dentro de la corte imperial, siendo el padre Orozco el confesor del entonces embajador español ordinario, el marqués de Castañeda, a quien, además, estaba dedicada la obra. Hay que tener en cuenta que en ese momento había en Viena otro embajador, en este caso extraordinario, el conde de Oñate, siendo Castañeda una figura cercana a los reyes de Hungría, lo que pudo servir a Allegretti para establecer lazos con la futura pareja imperial. Quedaría por clarificar, a falta de un registro documental, la posible relación de Allegretti con el influyente confesor de la reina, don Diego de Quiroga, si bien su papel dentro de su capilla — de la que pronto nombrarían a Allegretto Capellán de Honor- apunta a algún tipo de vínculo. Sea como fuera, lo cierto es que, a partir de entonces, observamos una gran confianza por parte de Castañeda hacia el raguseo y cierta predilección de la reina María Ana con él ${ }^{33}$.

Su siguiente cometido, en 1636, le llevó a Silesia, junto a la frontera con Polonia. Un año antes, Ladislao IV había frustrado las esperanzas de Madrid tras renovar la tregua con los suecos - tratado de Stuhmsdorf, septiembre de 1635-. Un acuerdo al que siguió la desmovilización de un número considerable de soldados levantados por el rey polaco. El momento era clave, tras la ruptura entre España y Francia, embarcándose el conde de Oñate en la contratación por cuenta propia de diez regimientos polacos para que auxiliaran las posiciones del sur y el oeste del Imperio ${ }^{34}$. Uno de los encargados de llevar adelante esta leva fue Allegretti, quien, por orden del conde, se trasladó a Silesia, donde desde el principio de la guerra se concentraban las tropas provenientes de Polonia para pasar al Imperio ${ }^{35}$. Dicha labor fue reconocida más tarde por el Consejo de Estado de Madrid como uno de los primeros logros diplomáticos del raguseo. Y todo ello, a pesar de que estas tropas terminaron causando más daño que otra cosa, al unirse muy tarde a la campaña, lo que llevó al propio conde de Oñate a tildarlas años más tarde de «nocivas» ${ }^{36}$.

${ }^{33}$ GONZÁLEZ CUERVA, 98 (Roma, 2018): 72-87.

${ }^{34}$ HÖLBERT, 2018. SKOWRON, 2015: 19-37.

35 Consejo de Estado, 1-IV-1636, AGS, EST, 2337, f. 64. Consejo de Estado, 20-XII-1638, AGS, EST, 2339, f. 78.

${ }^{36}$ Consejo de Estado, 7-V-1646, AGS, EST, 2810. La corte al conde de Monterrey, San Lorenzo, 23-X-1649, AHN, EST, 2259. Voto particular del conde de Oñate, 24-VIII-1640, AHN, EST, 674. 


\section{El Tratado de Nápoles (1638-1640)}

La labor de Allegretti en Silesia con las fuerzas polacas marcó su siguiente destino. En el año 1638, el príncipe Juan Casimiro Vasa, hermano de Ladislao IV, emprendió un viaje a Madrid con el objetivo de obtener un cargo de Felipe IV. Una empresa que respondió a las promesas hechas durante años por la diplomacia hispana a los Vasa polacos con el fin de atraerlos en la contienda europea. Sin embargo, el príncipe nunca llegó a España, pues fue interceptado por los franceses en las costas de Niza, siendo encarcelado por orden del cardenal Richelieu. Este suceso inició toda una serie de negociaciones entre las cortes de Varsovia, Viena, Nápoles y Madrid, que pronto derivaron en la conformación de un proyecto para involucrar al rey de Polonia en la guerra con Francia y hacerse con los servicios de un gran ejército polaco. Detrás de esta negociación estuvo el virrey de Nápoles, el duque de Medina de las Torres, que llegó a un acuerdo con el agente de Ladislao IV en la zona, Francisco de Biboni, que implicaba la conformación de un ejército ${ }^{37}$. Un trato que apenas tuvo en cuenta la opinión de la corte imperial, como tampoco la del embajador español, el marqués de Castañeda — Oñate había partido en 1637-, lo que dio pie a toda una serie de desencuentros en los que Allegretti jugó un papel central.

El raguseo viajó a Polonia en dos ocasiones durante esos años. En la primera, en 1639, fue como acompañante de don Fernando de Monrroy, sobrino de Castañeda, quien, por orden de este, se trasladó a la Dieta de Varsovia para tantear el ánimo de los polacos tras el encierro del príncipe ${ }^{38}$. Pero fue su segundo viaje, el de 1640, el que resultó ser mucho más problemático. Este fue decidido por el embajador español de mutuo acuerdo con Fernando III y su principal ministro Trauttmansdorff, y tenía como objetivo concretar algunas de las carencias que contenía el Tratado de Nápoles ${ }^{39}$. Esta misión fue totalmente desaprobada por el duque de Medina de las Torres, que consideró el acuerdo como cerrado, a la espera únicamente de ser ratificado, y juzgó el envío de Allegretti como una oportunidad que se brindaba a los polacos para renegociarlo $^{40}$. Al duque tampoco le gustó que el pacto negociado por él pasara por las manos de un agente, Allegretti, al que tildó de «ninguna sustancia», una opinión que fue compartida entonces por otros ministros ${ }^{41}$. En Viena, en cambio,

37 SKOWRON, 2013: 195-271. CONDE PAZOS, 33 (Salamanca, 2011a): 123-139.

38 Consejo de Estado, 19-XI-1639, AGS, EST, 2339, f. 33.

39 El marqués de Castañeda a Medina de las Torres, Ratisbona, 17-VII-1640, AGS, EST, 2363, f. 135. El marqués de Castañeda a Medina de las Torres, 21-VI-1640, AGS, EST, 3263, f. 131. f. 149 .

${ }^{40}$ El duque de Medina de las Torres a Felipe IV, Nápoles, 26-VIII-1640, AGS, EST, 3263,

${ }^{41}$ El duque de Medina de las Torres al Conde Duque de Olivares, Nápoles, 12-V-1640, AGS, EST, 3263, f. 82. Más adelante, Castañeda justificaría el envío de Allegretti por ser «platico, atento y con la lengua natural», El marqués de Castañeda a Medina de las Torres, 
juzgaron la materia de impracticable tal como estaba planteada, algo que achacaron al gran desconocimiento que se tenía en Nápoles del complejo sistema político polaco. Pronto, la misión de Allegretti se convirtió en un elemento más en las pugnas entre los ministros de Felipe IV, en las que participó, además de Castañeda y Medina de las Torres, el Cardenal Infante ${ }^{42}$. A todo ello se sumó un viaje problemático, al ser asaltado Allegretti cuando atravesaba Polonia, perdiendo la mayor parte de sus bienes ${ }^{43}$. Una agresión que pudo verse propiciada por el halo de secretismo que rodeó a su misión, refiriéndose a él Ladislao IV en sus cartas como «la persona que sabéis» ${ }^{44}$.

Una vez en Varsovia, Allegretti pudo comprobar las dificultades que había a la hora de encaminar el acuerdo, así como lo poco receptivos que se mostraban los polacos de cara a su ratificación. Los problemas del acuerdo estaban relacionados con el pago de los soldados y su paso por el imperio, así como con el papel que debía jugar Ladislao IV y su hipotética entrada en la guerra ${ }^{45}$. Una posibilidad, esta última, que prácticamente se disipó tras la liberación de Juan Casimiro por parte de Richelieu en la primavera de 1640 y la firma de un acuerdo por parte de los Vasa polacos, en el que se comprometían a no adoptar medida alguna contra el rey de Francia. A pesar de todo, durante el verano, el Cardenal Infante decidió enviar a Varsovia uno de sus coroneles, Pedro Rouco de Villagutiérrez, para que se encargara de la ratificación del acuerdo y el paso de las tropas. Este se encontró con un clima sumamente hostil a su llegada a la corte polaca, que trató de manera incesante de cambiar lo pactado en Nápoles, forzando indirectamente la cancelación del acuerdo. Además, Villagutiérrez juzgó el número de soldados comprometidos, 13.000, del todo excesivo, siendo estos muy difíciles de manejar. En su lugar propuso reclutamientos de un volumen menor, lo que, además, causaría menos problemas a su paso por el imperio ${ }^{46}$.

La salida de Villagutiérrez de Varsovia — agosto de 1640 - no puso fin a los acuerdos entre los polacos y Medina de las Torres, que aún se extenderían por dos años más, tras la llegada a Nápoles del secretario Adam Tytlewski ${ }^{47}$. Pero sí supuso un claro socavamiento de la posición del marqués de Castañeda,

Ratisbona, 17-VII-1640, AGS, EST, 2363. Para entonces Castañeda ya se había plegado a las presiones, señalando la conveniencia de sustituir a Allegretti por alguien de mayor porte «para sacar las cosas de duda y que las entienda mexor», El marqués de Castañeda a Medina de las Torres, Viena, 21-VI-1640, AGS, EST, 2363, f. 131.

${ }^{42}$ El duque de Medina de las Torres al Conde Duque de Olivares, Nápoles, 12-V-1640, AGS, EST, 3263, f. 82.

${ }^{43}$ Consejo de Estado, 7-V-1646, AGS, EST, 2810.

${ }^{44}$ Ladislao IV a Francisco de Biboni, Varsovia, 31-III-1640, AGS, EST, 3263, f. 53.

${ }^{45}$ Capitulos de cartas de Ladislao IV del 20-III-1640, AGS, EST, 3263, f. 117.

${ }^{46}$ Carta de Pedro Rouco de Villagutiérrez, Varsovia, VIII-1640, BNM, manuscrito 2371, f. 461.

${ }^{47}$ Este había sido uno de los principales interlocutores de Allegretti en Varsovia: Allegretti a Castañeda, Varsovia, 23-VI-1640, AGS, EST, 3263, f. 132. 
que se vio obligado a defenderse de las acusaciones de sus enemigos ${ }^{48}$. Para Allegretti, en cambio, su misión sirvió para ganar una mayor notoriedad entre los círculos de la corte imperial. Según las fuentes hispanas, poco después fue nombrado Capellán de Honor de la corte de Fernando III ${ }^{49}$.

\section{Milán, Múnich y Varsovia (1641-1648)}

La confianza depositada por la familia imperial sobre Allegretti quedó en evidencia en la siguiente misión que se le encomendó. A finales de 1640, una parte de la nobleza portuguesa se rebeló contra Felipe IV, poniendo al frente de la corona a Juan de Braganza. En aquel momento estaba desplazado en Alemania uno de sus hermanos, don Duarte Braganza, sobre el que el conde duque de Olivares siempre había tenido sospechas, por tratarse de un noble muy ambicioso y capaz. De hecho, su presencia en Alemania, junto a las fuerzas imperiales, estaba en parte motivada por el deseo del valido de mantenerle alejado del reino portugués. De manera que, cuando se conoció la noticia de la rebelión, Olivares dio orden de arrestarlo, pasando a una prisión en Graz. Se inició así a un largo encierro que causó gran revuelo internacional, pues parecía demostrado que Duarte no había tenido nada que ver con el golpe en Lisboa, algo que el propio don Francisco de Melo pudo apreciar después ${ }^{50}$. A pesar de todo, desde Madrid se prefirió mantener al portugués encerrado, planeando su traslado a alguna de las posesiones en Italia con el fin de garantizar su seguridad. Para ello, en un primer momento se pensó en utilizar la complicidad de los venecianos para llevar al preso por mar hasta la fortaleza de Castelnuovo, en Nápoles. Una solución que pronto se juzgó impracticable. Finalmente se decidió su traslado por la vía terrestre, por los valles transalpinos, hasta Milán ${ }^{51}$. Este viaje estuvo sujeto a la máxima discreción y, por orden de la emperatriz María Ana y el II marqués de Castel Rodrigo, fue confiado a Allegretto Allegretti, entre otros. La misión no estuvo exenta de ciertos peligros, como el causado por un clérigo portugués que fue detenido por planear la liberación de Duarte en Graz, si bien fue finalizada con éxito, lo que le valió a Allegretto dos cartas de felicitación, una de la emperatriz y otra de Castel Rodrigo ${ }^{52}$.

${ }^{48}$ El marqués de Castañeda a Medina de las Torres, Ratisbona, 17-VII-1640, AGS, EST, 2363, f. 135.

49 Consejo de Estado, 7-V-1646, AGS, EST, 2810.

50 VERMEIR, 2006: 258-259. VALLADARES, 1998: 101-106.

${ }^{51}$ Felipe IV al conde de Siruela, Madrid, 28-XII-1641, AGS, EST, 3454, f. 183.

${ }_{52}$ Consejo de Estado, 7-V-1646, AGS, EST, 2810. Felipe IV al conde de Siruela, Madrid, 30-III-1642, AGS, EST, 3455. 
Con semejantes respaldos, Allegretti entró en contacto con la corte de Madrid con el objetivo de que se le hiciera efectiva la merced obtenida en 1628 y se le concedieran nuevas prebendas. Ya en 1639, el raguseo había dirigido una misiva a la corte con este fin, sin éxito ${ }^{53}$. En 1642 lo volvió a hacer, esta vez para pedir que se le aumentara la suma hasta los 300 ducados, así como un sueldo, en el ínterin, de entretenido de 30 escudos, pagado por la caja de la embajada alemana. Unas pretensiones que se vieron convenientemente respaldadas por sendas cartas de recomendación de la emperatriz María Ana y el marqués de Castel Rodrigo, logrando que el Consejo de Estado español aprobara el pago de la merced, al menos en la cuantía original ${ }^{54}$. Pero su concreción quedó pendiente de la aprobación del Consejo de Italia, donde debió quedar bloqueada, pues en 1646 el raguseo de nuevo volvió a escribir a la corte para que se le pagara. En esta ocasión, Allegretti aportó un nuevo memorial recopilando sus servicios, al que sumó una carta del propio Fernando III, obteniendo un resultado muy similar, con orden tanto del rey como del Consejo Estado para que se le hiciera efectivo el pago - lo que, como veremos más adelante, no ocurrió — 55 .

El año de 1646 fue importante para la carrera de Allegretti, al morir, en mayo, su principal valedora en la corte, la emperatriz María Ana. Lo cierto es que la relación entre ambos debió ser bastante estrecha, como ya apuntó el marqués de Castel Rodrigo en la carta de recomendación antes citada. Desaparecía así una figura clave en el escenario centroeuropeo, que durante años había trabajado en favor de la colaboración entre las dos ramas de la dinastía. La muerte de la emperatriz supuso un duro revés para el grupo español de la corte, que perdió gran parte de su influencia, lo que se vio reflejado en una serie de políticas emprendidas a partir de entonces por parte de Viena, cada vez más alejadas de los parámetros familiares, que culminarían meses más tarde con la firma de la paz de Westfalia. Para figuras como Allegretti, pertenecientes al entorno más cercano de la emperatriz, su muerte supuso un paso atrás de cara a sus pretensiones en la Monarquía, al ser esta su principal protectora. A partir de entonces, este tuvo que recurrir a la intercesión de la embajada española y a cartas de recomendación del propio Fernando III, para hacer valer sus méritos y pedir nuevas mercedes a Felipe IV. Esta dependencia poco a poco ligó su suerte a la cada vez más compleja relación entre las dos ramas de la dinastía austriaca. Allegretti permaneció en Viena, con el resto de los criados dejados por la emperatriz fallecida ${ }^{56}$. Allí vivió de primera mano los cambios de una

${ }^{53}$ Consejo de Estado, 25-IX-1639, AGS, EST, 2340, f. 26.

${ }^{54}$ Consejo de Estado, 16-VIII-1642, AGS, EST, 2805. Registro de consultas, 7-X-1642, AHN, EST, 1. 372.

${ }_{55}$ Consejo de Estado, 7-V-1646, AGS, EST, 2810.

56 Allegretti aparece en el listado de criados como capellán, gozando de una ración de 7 reales y gajes por 200 florines, Lista de las criadas y criados españoles que ha dejado la Emperatriz nuestra señora que está en el cielo..., AGS, EST, 2347. 
corte en profunda transformación, tanto política como culturalmente, en la que la preeminencia hispana dejaba paso a otras corrientes - en el caso del idioma, al italiano, que Allegretti tan bien dominaba- y en el que la competencia de grupos dentro de la corte se hizo cada vez mayor ${ }^{57}$. A pesar de todo, siguió fiel a su servicio a la rama hispana, colaborando de manera activa con la embajada, al tiempo que cultivaba su vínculo con la emperatriz fallecida, que tanto le había beneficiado. Un ejemplo lo encontramos en 1654, cuando visitó al cardenal Harrach, a quien regaló una pequeña estampa de María Ana ${ }^{58}$.

En ese mismo año de 1646, el raguseo se trasladó a Múnich, donde participó en las negociaciones para liberar al II marqués de Mortara, quien había caído preso de los franceses en San Lorenzo de Mongay — septiembre de 1645 - El objetivo de Allegretti era intercambiar al marqués por el general Reinhold von Rosen, cautivo desde la batalla de Mergentheim - mayo de 1645-, por el que los bávaros pedían 20.000 escudos, la misma cifra que los franceses exigían por Mortara ${ }^{59}$. Sabemos por otras fuentes que ambos militares recuperaron su libertad a finales de ese año, aunque no podemos corroborar que esto se debiera a las gestiones del raguseo.

Dos años más tarde, en 1648, la embajada española en Viena volvió a recurrir a Allegretti para que fuera a Varsovia. Para entonces, la situación en Polonia-Lituania había empeorado mucho, tras el estallido de la rebelión cosaca y el fallecimiento de Ladislao IV — mayo de 1648 - Esta muerte no había sido prevista por ninguna de las dos ramas de la Casa de Austria, que no contaban en aquel momento con ningún tipo de representación en la zona. Para suplir dicha carencia, el duque de Terranova, entonces embajador español, dio orden a Allegretti para que partiera a Polonia y de paso preparara el terreno para la futura elección. Su instrucción, firmada en Praga en junio de 1648, revela muchas de las preocupaciones e incógnitas que entonces había en la embajada en torno a Polonia, como era la propia muerte de Ladislao, juzgada de repentina, por lo que debía averiguar si podía haber sido asesinado. El raguseo también llevaba orden de informarse sobre el testamento del rey, particularmente sobre todo lo referente a las rentas que este poseía en Nápoles, así como de sus derechos sobre la corona sueca. Sin embargo, fue la futura elección real la que copó la mayor parte de su instrucción. Allegretti debía indagar en el ánimo de los nobles polacos, señalando las posibles facciones y sus líderes, y quienes eran los candidatos con mayores posibilidades para reinar ${ }^{60}$. Ladislao IV no había dejado hijos vivos, pero sí tenía dos hermanos: el ya mencionado Juan

57 MAREK, 2018. HÖLBERT, 2018.

${ }^{58}$ CATALANO y KELLER, 2010: 775.

${ }^{59}$ Consejo de Estado, 19-VI-1646, AGS, EST, 2347.

${ }^{60}$ Instrucción y orden que el duque de Terranova dio a Allegretto Allegretti para la jornada de Polonia, 6-VI-1648, AGS, EST, 2352. 
Casimiro que viajó a España y Carlos Fernando, obispo de Breslavia. Ambos pugnaron por el trono, recibiendo Allegretti la orden de apoyar a los dos, si bien en secreto se le comunicó que procurara respaldar al más pequeño, Carlos Fernando, pues Juan Casimiro se había mostrado muy voluble ante los intentos de la diplomacia francesa de ganarlo cuando fue cardenal en Roma. Terranova también le transmitió de palabra el proyecto que existía en Viena de encaminar una candidatura propia, la del archiduque Leopoldo, la cual tuvo un corto recorrido $^{61}$. Antes de partir mantuvo una breve comunicación con Fernando III, actuando en Polonia en defensa de los intereses de las dos ramas ${ }^{62}$.

En un primer momento, el envío de Allegretti se planteó como una solución perentoria ante la falta de representación durante el interregno y, en Madrid, pronto se decidió el envío del marqués de la Fuente, entonces embajador en Venecia, para que se hiciera cargo de la elección. Pero este no pudo salir de la república a tiempo, por lo que finalmente Allegretti quedó como único representante español en la zona ${ }^{63}$. No obstante, no actuó solo, contando con la complicidad del nuncio papal, Giovanni de Torres, así como de uno de sus secretarios, con quienes tuvo orden de colaborar ${ }^{64}$. Esto no impidió que, de nuevo, llovieran críticas desde la corte de Madrid por su bajo perfil, como las de Medina de Torres, que volvió a referirse a Allegretti como «flaço» y de poca consideración ${ }^{65}$.

El raguseo estuvo siete meses en Polonia durante el año 1648. A lo largo de este tiempo no dejó de enviar avisos a la embajada, en los que detalló el desarrollo de los acontecimientos, así como el alineamiento de los diversos nobles. De manera que, por ejemplo, situó al canciller Jerzy Ossolinski, figura de mayor ascendencia dentro de la corte de Varsovia, en el campo francés ${ }^{66}$. Allegretti también entró en contacto con los dos hermanos Vasa que pugnaron por el trono. Con Juan Casimiro lo hizo por iniciativa del príncipe, quien con una serie de excusas concertó un encuentro que, más tarde, Allegretto temió que pudiera ser interpretado como una muestra de apoyo de Felipe IV a su candidatura. Por ello, el raguseo también trató de entablar una entrevista con Carlos Fernando, para lo cual entró en contacto con su confesor y un miembro de su

${ }^{61}$ El duque de Terranova al archiduque Leopoldo, Linz, 27-VII-1648, AGS, EST, 2351. Terranova pidió máxima discreción sobre este punto: «Con grandissima atención a no dar mucho motivo en los discursos que tuviere a que nadie entienda que la Casa de Austria quiere ni solicita aquella Corona».

${ }_{62}$ La corte al conde de Monterrey, San Lorenzo, 23-X-1649, AHN, EST, 2259.

${ }^{63}$ Al marqués de la Fuente, orden de lo que debe hacer en la jornada que hace a Polonia, Madrid, 5-VIII-1648, AHN, EST, 2661, f. 181.

${ }^{64}$ El nuncio Torres al duque de Terranova, Varsovia, 29-VII-1648, AGS, EST, 2351.

${ }^{65}$ Consejo de Estado, 13-VIII-1648, AGS, EST, 2351.

${ }^{66}$ Allegretto Allegretti al duque de Terranova, Varsovia, 29-VII-1648, AGS, EST, 2351. Copia de carta de Allegretti al duque de Terranova, Varsovia, 22-VII-1648, HHStA, Polen I, 62, f. 63. 
capilla, encuentros en los que el nuncio hizo de intermediario ${ }^{67}$. A largo plazo, la influencia externa en la elección demostró ser limitada, al estar el reino polaco-lituano demasiado centrado en el problema cosaco. Y tras la derrota de Piławce - septiembre de 1648 - la mayoría de la nobleza optó por la vía de la conciliación que parecía representar la candidatura de Juan Casimiro, siendo este proclamado rey el 20 de noviembre ${ }^{68}$.

\section{Constantinopla (1649-1650)}

La labor de Allegretti durante la elección real fue valorada de manera positiva por la corte imperial y, muy especialmente, por el duque de Terranova, quien añadió que todo lo había logrado con apenas una ayuda suya de 500 taleros, así como con otros 1.000 florines que el raguseo había puesto de su bolsi1lo. Allegretti obtuvo una carta de felicitación de Fernando III, así como otra mucho más discreta del príncipe Carlos Fernando Vasa, en la que agradecía su apoyo y, en general, el de la Casa de Austria ${ }^{69}$. Estas misivas le debían servir para culminar su próximo viaje y obtener nuevas mercedes. En 1649, Allegretto Allegretti se dispuso a unirse a la comitiva de la nueva reina, Mariana de Austria, en su viaje a Madrid. Una jornada que, como ya señaló Luis Tercero Casado, puso sobre la palestra las tensiones existentes en las relaciones entre las dos ramas tras la firma de la paz de Westfalia ${ }^{70}$. El raguseo viajó hasta España como capellán de la reina, limosnero y cura de palacio. Una labor que posteriormente rememoraría con orgullo y que contó con la aprobación de Fernando III ${ }^{71}$. No obstante, su estancia en Madrid apenas se dilató unas semanas, al tener que partir a una misión de una naturaleza delicada.

Durante el verano de 1649 llegó a España procedente de Ragusa y Nápoles una supuesta embajada enviada por el Imperio Otomano. El objetivo de esta fue toda una incógnita para la corte hasta apenas unas semanas antes de la llegada de la reina, cuando fue recibida por Felipe IV, y consistía en una propuesta de paz entre el Rey Católico y el sultán otomano. Una opción que, de cumplirse, podía suponer un auténtico vuelco en las relaciones internacionales de la época, pues lo máximo que se había tratado hasta entonces eran treguas ${ }^{72}$. El contexto del momento era importante: unos meses antes se había producido

${ }^{67}$ Allegretto Allegretti al duque de Terranova, 15-VII-1648, HHStA, Polen I, 62, f. 49.

68 JASIENICA, 1992: 25-27.

69 Carta de Carlos Fernando Vasa a Felipe IV, Varsovia, 5-XII-1648, AHN, EST, 2259.

70 TERCERO CASADO, 71/239 (Madrid, 2011): 639-664.

${ }^{71}$ Consejo de Estado, 29 de septiembre de 1651, AGS, EST, 3738. La corte al conde de Monterrey, San Lorenzo, 23-X-1649, AHN, EST, 2259. NOVO ZABALLOS, 2016: 29-91.

72 Consejo de Estado, 5-IX-1650, AHN, EST, 2871. 
en el palacio otomano una sublevación que terminó con el sultán Ibrahim ejecutado y su hijo Mehmed IV, de apenas seis años, en el poder. Un periodo turbulento, al que se sumó la guerra con Venecia, que tan malos resultados estaba dando a los turcos en el aspecto naval. Esta coyuntura era la que, para el Consejo de Estado español, podía explicar el envío unilateral desde Constantinopla de un embajador. Lo cierto es que no era la primera vez que en Madrid se hablaba de una hipotética paz con la Puerta, y unos años antes había llegado a España un enviado judío con una serie de propuestas de un sentido similar ${ }^{73}$. Pero nunca se había realizado un ofrecimiento tan abierto y aparentemente formal como en 1649. A pesar de todo, aún existían muchas incógnitas en torno a las intenciones reales de la embajada, e incluso sobre si se trataba de una misión genuina. Estas dudas fueron alimentadas por las increíbles propuestas hechas por el enviado durante las semanas siguientes, así como por su permeabilidad a los ofrecimientos hechos desde la corte ${ }^{74}$. Al final, esta decidió tantear la veracidad de todo aquel negocio, en un intento de establecerse como mediadora en una hipotética paz turco-veneciana. Para esto envió a un agente a la zona: Allegretto Allegretti.

Los motivos que llevaron a la corte a optar por Allegretti fueron variados, y estuvieron relacionados con sus capacidades idiomáticas y su condición de raguseo, que lo convirtieron en un canal de comunicación idóneo con el mundo otomano. También es probable que jugara a su favor su condición de ministro de perfil bajo, toda vez que en Madrid se quería mantener un tono discreto en la negociación - e incluso desembarazarse de la misma, llegado el caso- - . Fue el II marqués de Castel Rodrigo, entonces mayordomo del rey, quien recomendó al raguseo, con quien ya había cooperado en sus días como embajador en Viena. La misión no estaba exenta de algunos riesgos pues, como más adelante se señaló, los turcos no siempre respetaban la inmunidad diplomática y, por ejemplo, en aquel momento el bailo veneciano vivía preso en Constantino$\mathrm{pla}^{75}$. Las instrucciones dadas a Allegretto establecían que iba como mero portador de cartas, lo que cercenaba por completo su capacidad de negociación. Su viaje debía servir para verificar las propuestas hechas por el embajador otomano, así como tratar de encaminar la mediación hispana en una hipotética paz turco-veneciana. Allegretti iría en compañía de uno de los servidores del embajador otomano, llamado en las cartas Delaver - y con el que el raguseo no terminó en muy buenos términos-, procurando en todo momento colaborar con los venecianos ${ }^{76}$. Para ello, la corte escribió a la república para que enviaran a

${ }^{73}$ Papeles relativos a un hebreo que vino de Constantinopla, XII-1642, AHN, EST, 2849.

${ }_{74}$ Amete Aga a Felipe IV, Madrid, 16-IX-1649, AHN, EST, 2877.

75 Voto particular del conde de Monterrey, s. f. AHN, EST, 2877.

${ }^{76}$ Instrucciones que se dio a Allegretto Allegretti para pasar a Constantinopla, s. f., AHN, EST, 2871. 
un agente a Nápoles y que este se uniera a la comitiva, cosa que la Serenísima no admitió. Esto no impidió que más adelante el raguseo se reuniera al menos en dos ocasiones con el bailo ${ }^{77}$.

La salida de Allegretti de Madrid se produjo en los primeros días de noviembre de 1649, pasando a Denia y a Nápoles, donde fue recibido por el virrey, el conde de Oñate ${ }^{78}$. A continuación, el grupo atravesó el Adriático, entrando en la ciudad de Ragusa en febrero de 1650. Allegretti llevó dos cartas del rey para las autoridades de la república, lo que dio inicio a nuevas propuestas de protección y comercio ${ }^{79}$. Tras ello se internó en los Balcanes, hasta Sofía y Constantinopla, donde llegó el 31 de marzo de 1650. Una vez allí, su idea era la de alquilar un aposento particular, lo que hubiera garantizado cierta discreción a su misión. Pero el turco que los acompañaba se adelantó para avisar de su llegada, regresando más tarde con un servidor de la corte que los escoltó hasta una residencia oficial. A partir de ese momento, los movimientos de Allegretti fueron totalmente controlados por los otomanos, lo que despertó toda clase de sospechas entre el resto de las legaciones. Las siguientes semanas estuvieron marcadas por las audiencias entre el raguseo, el gran visir Kara Mustafá y varios cortesanos destacados, así como por sus intentos para encauzar una paz con Venecia. Pero pronto se hizo evidente que los turcos no estaban dispuestos a abandonar la isla de Candia, un punto que en Madrid se había fijado como línea roja para negociar. El tiempo que estuvo en Constantinopla sí que sirvió a Allegretti para comprobar de primera mano los problemas internos del palacio otomano - llegó a ser testigo de un enfrentamiento armado entre Sipahi y soldados-, así como del clima de malestar existente dentro del Imperio Otomano. Su estancia también fue aprovechada para establecer nuevas fuentes de información, acudiendo en concreto al traductor del residente imperial, Nicusius Panayoti, para que remitiera avisos ${ }^{80}$. Para mayo de 1650 Allegretti ya se disponía a partir de Constantinopla, tras haber fracasado el intento de mediación y haberse negado el gran visir a mandar nuevas credenciales a su embajador. A su regreso a Madrid llevó varios presentes enviados por la corte otomana, aunque él renunció a los regalos que le ofrecieron ${ }^{81}$. A finales de verano la corte española dio por suspendida la negociación.

${ }_{77}$ El marqués de la Fuente, Venecia, 4-VI-1650, AGS, EST 3549, f. 128.

${ }^{78}$ En opinión de la corte, Allegretti cometió en Nápoles uno de los errores más graves de su misión, pues no quiso reunirse con el residente de Venecia en esa ciudad. Una actitud que iba en contra de sus instrucciones y provocó una queja de la república, lo que finalmente aceleró su regreso de Constantinopla, Don Pedro Coloma a Allegretti, Madrid, 5-V-1650, AHN, EST, 22871.

${ }^{79}$ Consejo de Estado, 7-VII-1650, AHN, EST, 2871.

${ }^{80}$ Al virrey de Nápoles, Madrid, 6-XI-1650, AHN, EST, 2781.

${ }^{81}$ Esto siempre según la versión de Allegretti, pues según los venecianos, el raguseo recibió «un regalo muy desigual al grado que tenía y a lo que los otomanos suelen usar, agasajo 
Unos meses más tarde, Allegretti confeccionó dos documentos para la corte. El primero era una larga relación sobre su viaje en la que, entre otras cosas, se defendía de las acusaciones que le hacían los venecianos ${ }^{82}$. En el segundo hacía una descripción del Imperio Otomano, que incluía los motivos por los que, a su juicio, había caído en la decadencia, que se remontaban al sultanato de Murad IV - 1623-1640 - y los gastos causados por la guerra en Irán ${ }^{83}$. Dicha relación concluía con un llamamiento a Felipe IV para que firmara la paz con Francia y aprovechara la postración en la que se encontraban los otomanos para reorientar todos sus esfuerzos en la liberación de los cristianos balcánicos. Este proyecto probablemente respondía a las ideas de juventud del raguseo - el Regno de gli Slavi de Mavro Orbini fue publicado en 1601-, pero fue juzgado por el Consejo de Estado como todo un desatino, dado el estado en el que se encontraba la Monarquía tras los desórdenes últimos y el poco crédito que daban al apoyo de los griegos y los otros pueblos de la región ${ }^{84}$.

\section{ESPERANZAS FRUSTRADAS (1651-1653)}

La vuelta de Allegretti de Constantinopla fue acompañada de un nuevo intento para que la corte española hiciera efectivas sus promesas y le fueran concedidas nuevas mercedes. Ya en 1649, con motivo de su viaje con la reina, Felipe IV dio orden al Consejo de Italia para que estudiara su caso, se hiciera cargo de la merced eclesiástica de 150 ducados concedida en 1628 y, tras más de veinte años sin cobrarla, le fuera aumentada hasta los 300 escudos $^{85}$. En 1650 sus pretensiones fueron bastante más altas, toda vez que había realizado un servicio tan notable como ir a Constantinopla por orden del rey. Además, a su paso por Italia, Allegretti trajo la noticia de la capitulación de Porto Longone, una de las plazas estratégicas de la Monarquía en Italia, así como una recomendación de Juan José de Austria para don Luis de Haro ${ }^{86}$. Una noticia que le valió al raguseo una abadía de Felipe IV — sin que se determinase cual-, que, sin embargo, trató de trocar por un hábito para su primo, el barón Allegretti ${ }^{87}$. En cuanto a su pensión, el rey decidió aumentarla hasta los mil

muy extraordinario», El marqués de la Fuente a Felipe IV, Venecia, 16-VII-1650, AGS, EST, 3549, f. 153.

${ }^{82}$ Relación que hace don Allegretto Allegretti de su viaje a Constantinopla, 31-VIII-1650, AHN, EST, 2871.

${ }^{83}$ Relación del estado del Imperio Otomano hecha por monseñor Allegretti al rey Felipe $I V$, RAH, K-12, ff. 130 y ss.

${ }^{84}$ Consejo de Estado, 20-X-1650, AHN, EST, 2871.

${ }^{85}$ El rey al conde de Monterrey, San Lorenzo, 23-X-1649, AHN, EST, 2259.

${ }^{86}$ Carta de Juan José de Austria a Luis Méndez de Haro, VIII-1650, RAH, A-103, ff. 242-243.

87 Consejo de Estado, 10-IX-1651, AGS, EST, 3738. 
escudos, que más tarde situó en los puestos vacantes del obispado de Agrigento -Sicilia- ${ }^{88}$.

Fue aquí, de nuevo en el Consejo de Italia, donde empezaron a surgir los problemas, pues este se negó a emitir los despachos pertinentes para que Allegretti pudiera cobrar su sueldo, amparándose para ello en una orden previa del propio monarca en la que prohibía nuevas concesiones, al menos hasta que el obispado quedara efectivamente vacante - algo que no ocurrió hasta un año más tarde, con la muerte de Francesco Traina-. Una orden que, como el propio Allegretti señaló, no se estaba cumpliendo en el Consejo de Aragón, señalando otros casos en los que estos despachos sí se habían emitido ${ }^{89}$. Por otra parte, el raguseo se enzarzó durante los primeros meses de 1651 en una larga negociación por cuenta de la abadía que había recibido, al resistirse la corte a mutarla por un hábito ${ }^{90}$. Allegretti, además, pidió un sueldo de entretenido de la caja de la embajada alemana, el cual le fue concedido y situado en 20 escudos al mes ${ }^{91}$. Una cifra muy baja en opinión del raguseo, pues no llegaba a cubrir los 12 reales de ración al día que gozó como limosnero de la reina Mariana $^{92}$. En octubre, ante las súplicas de Allegretti, la corte sumó otros 5 escudos a su sueldo de 20, con advertencia de que no se le admitirían más réplicas $^{93}$. De hecho, unos meses antes, en abril de 1651, Felipe IV había expedido cartas a su embajador en Viena, el III marqués de Castel Rodrigo, para que se encargara de darle empleo en aquella corte ${ }^{94}$.

Allegretti tampoco tuvo una mejor suerte con su pensión eclesiástica situada en las vacantes del obispado de Agrigento, donde fue el segundo entre los pensionarios por el volumen de dinero ${ }^{95}$. Pero la desgracia quiso que el primero fuera el cardenal Trivulzio, a quien se había prometido un total de 10.000 ducados, repartidos entre las diversas vacantes de Italia — correspondiéndole 1.811 escudos de la de Agrigento-- con orden expresa de que su pago precediera al de Allegretti ${ }^{96}$. Esto debió retrasar aún más cualquier cobro, si bien sabemos que para 1653 ya se hablaba en Viena de estas sumas. Ese mismo año, Alle-

${ }^{88}$ Felipe IV al conde de Monterrey, Madrid, 9-IX-1650. Felipe IV al Consejo de Italia, 14-X-1650, AHN, EST, 2259.

${ }^{89}$ Felipe IV al Consejo de Italia, El Pardo, 20-I-1651, AHN, EST, 1. 456. Consejo de Estado, 29-IX-1651, AGS, EST, 3738.

${ }^{90}$ Registro de consultas, 15-IV-1651, AHN, EST, 1. 373.

${ }^{91}$ Consejo de Estado, 10-IX-1651, AGS, EST, 3738.

${ }_{92}$ Consejo de Estado, 29-IX-1651, AGS, EST, 3738.

${ }_{93}$ Registro de consultas, 3-X-1651, AHN, EST, 1. 373.

94 Resolución del consejo, 3-IV-1651, AHN, EST, 1. 230, f. 97.

${ }_{95}$ A catorce de octubre de 1626..., AHN, EST, 2174.

${ }^{96}$ Consejo de Italia, 19-II-1652, AHN, EST, 2259. 
gretti pasó a Ratisbona, donde se reunió la Dieta para elegir a Fernando IV como Rey de Romanos ${ }^{97}$.

Durante estos últimos años de su vida observamos un cambio de orientación en el servicio de Allegretti, que fue basculando cada vez más hacia la órbita de la corte imperial. Lo cierto es que el raguseo siempre había mantenido estrechos contactos con Fernando III y, si bien los últimos tres años había estado centrado en el servicio de la corte hispana - y estaba situado, claramente, entre los partidarios de la Monarquía Católica dentro de la corte imperia $^{98}$ - esto no fue sino un mero paréntesis dentro de una actividad focalizada en Viena, donde había establecido su residencia. Es posible que dicha aproximación se debiera a las dificultades de la Monarquía a la hora de aportarle una gratificación fija; o a las escasas posibilidades de ascenso que Madrid parecía ofrecer, toda vez que había tardado más de dos décadas en hacerle efectiva su primera pensión, lo que, probablemente, se debía a que no contaba con patrón firme en España. Lo cierto es que el caso de Allegretti no fue único durante esos años, en que los medios escasearon y el sistema de pensionarios de la embajada cayó en declive ${ }^{99}$. Una realidad que, a nuestro entender, quedó evidenciada en su siguiente misión, la cual contó con el apoyo tácito de la diplomacia española, pero se hizo exclusivamente a instancias de la imperial.

\section{Moscovia (1654-1656)}

En el otoño de 1654 llegó a Viena una embajada moscovita liderada por Ivan Baklanovski e Ivan Mikhalov. Se trataba de la primera representación formal rusa en el imperio tras casi treinta años, y su cometido oficial era anunciar la muerte de Miguel I y el ascenso al trono de su hijo, Alejo Romanov, producido hacía casi nueve años. En realidad, la llegada de la embajada respondía a la grave situación establecida en Polonia-Lituania, un reino que los moscovitas habían invadido en la primavera de 1654. A pesar de los reiterados intentos de conciliación, Juan Casimiro nunca alcanzó una paz firme con los cosacos, quienes, tras años de combates, terminaron buscando la protección de un príncipe poderoso. Este no fue otro que el gran duque de Moscovia, Alejo I, con el que compartían la fe ortodoxa. El tratado de Pereyáslav, acordado en enero de 1654, dio inicio una escalada en la zona, que primero llevó a los moscovitas a invadir Lituania y que culminó a lo largo del verano de 1655, con el ataque de

97 CATALANO y KELLER, 2010: 695.

98 Por ejemplo, Gualdo Priorato situó a Allegretti en el entorno del príncipe de Auersperg, primer ministro de Fernando III y defensor de la alianza con Madrid, GUALDO PRIORATO, 1669, vol. I: 592.

${ }^{99}$ MAREK, 2018. 
Carlos X de Suecia sobre Polonia y el estallido la Segunda Guerra del Norte ${ }^{100}$. El objetivo de la corte de Alejo I con aquella embajada era tantear la posición de las cortes occidentales ante su acometida sobre Lituania y formaba parte de una ofensiva diplomática más amplia. El moscovita ofreció renovar los lazos de amistad establecidos entre las dos cortes en tiempos de Maximiliano I y Rodolfo II, y asegurarse, de paso, la no intervención de Fernando III en el escenario polaco-lituano. Un objetivo que pronto chocó con los reiterados llamamientos hechos por los diplomáticos polacos en Viena para que se les prestara ayuda - embajada del obispo de Poznan-. La respuesta del emperador fue el envío de una embajada a Moscovia que renovara los lazos de amistad y tratara de establecer la mediación imperial en la guerra polaco-moscovita. Un cometido que fue confiado a Allegretto Allegretti y a Johann Theodor von Lorbach, los cuales partieron hacia la corte moscovita en junio de $1655^{101}$.

Una vez más, la presencia de Allegretti se explica por sus conocimientos idiomáticos, así como por su amplia experiencia diplomática, liderando una comitiva de en torno a 23 personas en la que hubo varios raguseos. Lorbach, en cambio, fue incorporado de manera tardía, hablando exclusivamente alemán y latín ${ }^{102}$. Esto situó a Lorbach en una clara desventaja respecto a Allegretti, al no poder comunicarse directamente con las gentes de Moscovia. Lo cierto es que la relación entre ambos ministros terminó siendo muy tensa, lo que llevó a un arduo enfrentamiento tras su regreso. De hecho, conocemos bien los pormenores de la embajada gracias a sendas relaciones enviadas por cada uno de ellos a la corte vienesa, ambas plagadas de acusaciones mutuas ${ }^{103}$. Lorbach recriminó a Allegretti el no haber respetado su estatus como enviado, el haberlo presentado como ministro inferior en rango y, en definitiva, el haber querido copar todo el mérito de la misión. Además, cuestionó muchos de sus procedimientos, como el escaso celo mostrado por el protocolo - sobre todo en lo referente al tratamiento y los títulos dados a Alejo I-, así como por su empeño de rodearse de raguseos, con los que frecuentemente se comunicaba en su lengua natural, lo que le dejó a él aislado ${ }^{104}$. Por último, acusó a Allegretti de haber perdido la compostura en varios momentos, lo que le puso en evidencia pública. Alle-

100 FROST, 2003.

101 SCHWARCZ, 50 (Innsbruck, 2003): 29-42.

102 KONRÁDOVÁ y SMIŠEK, 2016.

103 La mayor parte de la documentación de esta misión la encontramos en HHStA, Russland I, 8 y Russland I, 9, siendo especialmente valioso el volumen III de este último legajo. También hallamos algunos documentos en HHStA, POLEN I, 68. Las dos relaciones, así como los papeles más relevantes, fueron publicados en MEJER, 2007.

104 Allerdurchlauchtigster grossmechtigister... Viena, enero de 1657, HHStA, Russland I, 9, C. 3, ff. 12-18. 
gretti, por su parte, contestó a estas acusaciones asegurando que Lorbach era un ministro del todo mediocre y que su papel durante la embajada fue nulo ${ }^{105}$.

Existe una tercera relación, importante para analizar el viaje a Moscovia. Esta fue la de Fran Đivo Gundulić (1633-1700), hijo del célebre poeta raguseo Ivan Gundulić, quien acompañó a la embajada y redactó varios años más tarde su propia memoria del viaje. Esta fuente es especialmente interesante, pues no estaba dirigida a la corte de Viena, sino que era más bien un recuerdo personal, y no trataba de defenderse de ningún tipo de acusación. Aun así, no podemos considerar la relación de Fran Gundulić como del todo imparcial, pues en ella se entrevé que mantenía algún tipo de vínculo personal con Allegretti, quien parece que le protegió. A pesar de todo, su relato contiene algunos pasajes críticos hacia él, como el ocurrido durante un banquete en la corte moscovita, en el que Allegretti terminó cediendo al cansancio y los excesos, por lo que Gundulić tuvo que hacerse cargo de la comunicación ${ }^{106}$.

El viaje de la comitiva se inició en junio de 1655 en la corte de Viena, pasando posteriormente a Praga, Dresde, Hamburgo, Lübeck y Revel. Un viaje largo, que trataba de sortear las graves confrontaciones de Polonia-Lituania y que permitió a Allegretti entrevistarse con varios de los más destacados dignatarios de esos lugares. A continuación, la embajada puso rumbo a la frontera moscovita, donde quedaron bloqueados durante unas semanas a la espera de ser escoltada por sus autoridades. La llegada a Moscú no se produjo hasta octubre de 1655 , siendo aposentados en una casa de piedra de gran comodidad. La primera audiencia ante Alejo se realizó unas semanas más tarde, el 25 de diciembre. Un encuentro de carácter protocolario, en el que estuvo presente buena parte de la corte - cuyos oficios Allegretti se preocupó en describir en su relación-, en una ceremonia donde le fueron entregados al Gran Duque regalos valorados en 30.000 florines. Durante los días siguientes se sucedieron las conversaciones, siendo el principal negociador moscovita Almaz Ivanov, encargado de los asuntos extranjeros de Alejo I. Estas pronto giraron en torno al peligro común que suponía el expansionismo sueco, ya que, para entonces, las fuerzas de Carlos X habían irrumpido en Polonia y amenazaban tanto a los ejércitos moscovitas en Lituania como la propia Bohemia, tras la caída de Cracovia a finales de 1655 . Hay que señalar que, en aquel momento y de manera paralela a la misión de Allegretti, se desarrollaba en Moscú una embajada sueca, dirigida por Gustav Bielke, que buscaba precisamente preservar la paz con los moscovitas ${ }^{107}$. Allegretti era consciente de ello, por lo que no recibió nada mal las insinuaciones que entonces se le hicieron para cerrar un acuerdo austro-moscovita contra el sueco - lo que parecía anunciar el fracaso de Bie-

105 Legatione di Moscovia, Anno 1656, Viena, 28-II-1656, HHStA, Russland I, 9, C. 9-3, f. 20.

106 Dicha relación, en italiano, fue publicada en DEANOVIĆ, 41 (Zagreb, 1948): 7-59.

107 DAHLGREN, 2007: 50-137. 
lke- Sin embargo, había partido de Viena con la orden expresa de no emprender ningún tipo de negociación en este sentido, ciñéndose estrictamente a su labor de mediación. Esta última función se vio favorecida por el rápido expansionismo sueco, que llevó a la corte moscovita a buscar un acuerdo de paz con los polacos. De manera que, para el 29 de diciembre, la corte rusa accedió a la mediación ofrecida por Fernando III, quedando únicamente por concretar la fecha y el lugar de celebración ${ }^{108}$.

Las semanas siguientes sirvieron para que Allegretti conociera mejor la realidad moscovita y se integrara en sus espacios de sociabilidad, participando en varias ceremonias y banquetes. Todo ello, a la espera de que desde Viena se le enviaran nuevas credenciales para que actuara como mediador. No fue hasta el verano de 1656 cuando finalmente ambas comitivas, polaca y moscovita, se reunieron en Vilna para negociar la paz, llegando Allegretti junto a los representantes de estos últimos. Sin embargo, estuvo claro casi desde un primer momento que su papel de árbitro no era del todo imparcial y que, en general, el raguseo se decantaba por la parte polaca, la más cercana a Fernando III, menos amenazante y, además, católica. Hay que tener en cuenta que, para entonces, la situación de la guerra polaco-sueca había dado un giro notable, tras el rápido avance de las posiciones de Juan Casimiro durante la primavera, la entrada en la contienda del elector de Brandemburgo en el lado sueco y la derrota de los polacos en la batalla de Varsovia -28-30 de julio-. Una situación que, en general, beneficiaba la posición negociadora de los moscovitas, quienes con su posicionamiento en la guerra podían reequilibrar el resultado final y que contaban con amplias conquistas en Lituania y Ucrania - incluyendo la propia ciudad de Vilna-. De hecho, para entonces, Alejo I ya había empezado a desviar a una parte de sus fuerzas hacia el norte para hacer frente a la amenaza sueca, una circunstancia que Allegretti trató de trasladar a los polacos, en un intento de reforzar su posición. Pero, según este, los negociadores de Juan Casimiro desoyeron dichos avisos, al desconfiar de sus intenciones. Más aún, según Allegretto, estos cometieron un grave error al dejar que los moscovitas presentaran abiertamente sus pretensiones para concertar una paz, las cuales fueron tan excesivas que a punto estuvieron de llevar a una ruptura de las conversaciones. Finalmente, se estableció una frontera natural en torno al río Dniéper que actuara como línea divisoria provisional entre las dos partes. Pero los moscovitas se resistieron a restituir sus conquistas en Lituania. Más aún, en un momento determinado, trataron de introducir en la negociación la posible sucesión de Alejo — o su hijo - al trono polaco-lituano, una cuestión que pareció sorprender a los negociadores polacos, así como al propio Allegretti que, desde un primer momento, se mostró contrario, por no responder a la paz justa que

${ }^{108}$ Allegretti y Lorbach a Fernando III, Moscú, 18-I-1656, HHStA, Russland I, 8, 2 ff. 27-35. 
decía defender su señor el emperador. Por supuesto, se trataba de una resistencia interesada y, en aquel momento, se estudiaba en la corte de Viena una solución similar para el trono polaco-lituano, en este caso en favor de un miembro de la Casa de Austria - si bien es harto improbable que Allegretti lo supiera— ${ }^{109}$. La cuestión de la sucesión pronto emponzoñó las conversaciones de paz, así como la posición mediadora de Allegretti, que no tardó en ser acusado por los moscovitas de instigar la guerra, por lo que finalmente se tuvo que retirar. Los polacos firmaron una tregua, dejando las manos libres a Alejo I para actuar contra Suecia, mientras que la cuestión de la sucesión moscovita quedó pendiente para una Dieta futura. Una puerta que se dejó abierta a los Romanov y que Allegretti encareció duramente a los negociadores polacos a su regreso de Vilna, por atentar directamente contra sus libertades y la posición de la Iglesia católica en aquel reino ${ }^{110}$.

La embajada moscovita fue la última misión diplomática de importancia de Allegretti, y probablemente la más controvertida, no solo por las críticas que Lorbach vertió posteriormente contra su persona, sino también por las noticias que durante los meses siguientes arribaron sobre su labor, que ponían en entredicho la voluntad de Fernando III de encaminar la paz. Unas noticias que también llegaron a Madrid de mano de su representante en La Haya, don Esteban de Gamarra, en las que se acusaba al intermediario imperial en Vilna - cuyo nombre nunca se llegó a citar- de turbar cualquier intento de paz ${ }^{111}$. Desconocemos si todo ello afectó directamente a la posición de Allegretti dentro de la corte imperial. Pero lo cierto es que, a partir de entonces, esta relegó a los raguseos en las siguientes misiones en Moscovia, optando, en cambio, por sus residentes en Polonia, de origen bohemio o alemán — Johann Christoph von Fragstein en 1657; Augustin von Mayerberg en 1661-.

La última mención que encontramos de Allegretti en las fuentes hispanas data de enero de 1657, como parte de una respuesta del recién nombrado embajador español en Viena, el marqués de la Fuente, a una propuesta del barón de Lisola para que la embajada recuperara la figura de residente, en desuso desde la década de 1630. Una propuesta que fue desestimada entonces por el marqués, quien la reformuló para que se estableciera una figura de menor peso y autonomía, la del asistente, proponiendo varios nombres. Entre ellos estaba el de Allegretto Allegretti quien, decía, ya cobraba un sueldo de la caja de la embajada española y en quien se podía confiar, siempre y cuando fuera «para cosas de menor manufactura $»^{112}$. Como vemos, a pesar de los numerosos servi-

\footnotetext{
109 Francisco de Lisola al príncipe de Auersperg, Torono, 26-VI-1656, AGS, EST, 2365.

110 Legatione di Moscovia, Viena, 28-II-1656, HHStA, Russland I, 9, C. 9-3, ff. 20-40.

111 Relación de lo que ha pasado en el Tratado de Vilna entre los comisarios del rey de Polonia y el Gran Duque de Moscovia. s. f., AGS, EST, 2092, f. 38.

${ }^{112}$ El marqués de la Fuente a Felipe IV, Viena, 24-I-1657, AHN, EST, 1. 125, f. 12.
} 
cios prestados a la Casa de Austria, Allegretti fue considerado por los españoles como una figura menor hasta prácticamente el último de sus días. Un año más tarde, en 1658, el raguseo moría en Fráncfort, lugar donde en aquel momento se estaba eligiendo a Leopoldo I como emperador ${ }^{113}$.

\section{Conclusiones}

Allegretto Allegretti fue una figura relevante dentro del entramado creado por los españoles en la corte imperial para encaminar el principio de colaboración dinástica. Durante los veinticinco años que estuvo en Viena, el raguseo actuó como eclesiástico y diplomático dentro de la corte imperial, convirtiéndose en un mediador entre ambos mundos, combinando su lealtad y servicio a la embajada española y a la familia imperial. Allí debió gran parte de su ascenso a la protección de la emperatriz María y, tras su muerte, vivió de primera mano el lento declinar del grupo español en aquella corte. A pesar de todo, Allegretti supo establecer un espacio propio gracias a sus dotes, destacando en los idiomas, y durante los últimos años se especializó en misiones en lugares considerados periféricos dentro de los estándares de la época, como eran Moscú o Constantinopla. En estas cortes los usos y la etiqueta eran diferentes a los de Occidente, lo que obligó al raguseo a mostrarse flexible, con mayor o menor éxito en sus cometidos. Unas misiones que, al igual que la influencia cambiante de los españoles en Viena, anunciaban grandes transformaciones en el panorama internacional, así como en la propia relación de fuerzas dentro de la familia austriaca.

En cierta manera, la figura de Allegretti representó un vínculo: el de la Monarquía Hispana con las distintas potencias y pueblos de la órbita eslavocatólica. Vínculo que, en el caso particular de la república de Ragusa, germen de la carrera de nuestro diplomático, remontaba sus orígenes a la Baja Edad Media, a la política mediterránea de la Corona de Aragón y al papel ejercido por la corte napolitana en el espacio adriático y el sureste europeo. Y que, a lo largo del siglo XVI, conectó directamente con Madrid, sustentado en una serie de intereses comunes, unos objetivos particulares - comercio, lucha contra el turco, promoción de los linajes raguseos- $-\mathrm{y}$ un fuerte componente de carácter ideológico y confesional. Este vínculo, gracias a figuras como la de Allegretti, que hizo las veces de canal de comunicación, se extendió a las otras cortes eslavo-católicas, destacando entre ellas la de Polonia-Lituania, todo ello en una Europa marcada por el auge y la expansión del ideario contrarreformista.

113 CATALANO y KELLER, 2010: 456.

Hispania, 2021, vol. LXXXI, n. ${ }^{\circ}$ 269, septiembre-diciembre, págs. 621-650, ISSN: 0018-2141, e-ISSN: 1988-8368 https://doi.org/10.3989/hispania.2021.015 
Pero se trataba de un vínculo en declive ya para el periodo que tratamos o, más bien, en profunda transformación, con una transición de su liderazgo dentro de la Casa de Austria en favor de Viena. Una corte donde la Monarquía Católica tendió a focalizar gran parte de su actividad en la Europa central y centro-oriental desde principios del siglo XVII. Todo un ejemplo de cómo la corte de Madrid, entregada a la política dinástica y la guerra con Francia, fue a largo plazo incapaz de mantener sus compromisos en la zona, tanto estratégicos - política adriática, ofensiva contra el turco-, como particulares —al no ser capaz de proporcionar visos de ascenso a sus partidarios-, elementos ambos sobre los que se había sustentado la relación. El caso de Allegretti ilustra los límites de la Monarquía a la hora de premiar e integrar a este tipo de sujetos, siendo considerado hasta el último de sus días como un ministro menor. Una opinión que contrastó con la de la corte imperial, que a largo plazo aportó una mayor ascendencia al raguseo.

En este sentido, la figura de Allegretti parece mostrar una dinámica de transición interna dentro de la casa en beneficio de Viena, que tendría continuación durante la generación siguiente y estaría ejemplificada en la figura de Fran Đivo Gundulić, quien, como vimos, acompañó al raguseo en su misión a Moscovia. Este también había inaugurado sus servicios a los Austria colaborando con Felipe IV, más concretamente con sus ejércitos en Italia. Pero pronto pasó a Viena, donde escaló posiciones gracias a la protección brindada por la emperatriz Leonor Gonzaga-Nevers, casándose en 1674 con una de sus servidoras, la condesa María Victoria Octavia Strozzi ${ }^{114}$. Es decir, a la sombra de la emperatriz y su entorno italiano y no del grupo español. Todo ello, en un tiempo en el que el componente confesional quedaba cada vez más desdibujado, al igual que la colaboración entre la Monarquía y Roma en el exterior. De manera que las esperanzas de los cristianos gobernados por los otomanos empezaron a dirigirse cada vez más a Viena y no a Madrid.

Este cambio se produjo en un contexto de grandes transformaciones en el ámbito internacional, con la irrupción paulatina de Moscovia / Rusia en los estándares del orden europeo, gracias, en parte, a los contactos emprendidos a mediados del siglo XVII. En este sentido, la negociación de Vilna, mediada por Allegretti, inauguró en Moscovia una política de aproximación hacia el mundo occidental, encarnada por la figura de Ordin-Nashchokin, que tenía entre sus objetivos la obtención de la corona polaca y la unión contra los turcos.

La culminación de este camino llegó a partir de 1683, tras la liberación de la ciudad de Viena de manos turcas, que pareció sancionar el fracaso de las políticas agresivas emprendidas por el palacio otomano tras su aparente recuperación a partir de la década de 1650. Un evento en el que Gundulić tomó una

114 ZLATAR, 1992b: 72-75. 
parte activa, residiendo a partir de entonces en la capital imperial, hasta su muerte, producida en el año 1700. Para entonces, la transición de estos vínculos ya se había completado, allanando el dominio de los Habsburgo austriacos sobre la órbita eslavo-católica y reforzando su vocación hacia los Balcanes.

\section{Bibliografía}

Bunes Ibarra, Miguel Ángel, «Avis du Levant: le réseau d'espionnage espagnol dans l'Empire ottoman à partir du Sud de l'Italie, à la Charnière des XVIe et XVIIe Siècles», en Béatrice Perez (ed.), Ambassadeurs, Apprentis Espions et Maîtres Comploteurs: Les systèmes de Renseignement en Espagne à l'époque moderne, París, Presses Paris-Sorbonne, 2010: 223-240.

Campanile, Filiberto, L'armi, overo Insegne dei nobili, scritte dal signor Filiberto Campanile, ove sono i discorsi d'alcune famiglie cosi spente come vive nel regno di Napoli, Nápoles, Antonio Gramignani, 1680.

Catalano, Alessandro y Keller, Katrin, Die Diarien und Tagzettel des Kardinals Ernst Adalbert von Harrach (1598 - 1667), Viena, Böhlau Verlag, 2010.

Conde Pazos, Miguel, «El Tratado de Nápoles: el encierro del príncipe Juan Casimiro y la leva de polacos de Medina de las Torres (1638-1642)», Studia historica. Historia moderna, 33 (Salamanca, 2011a): 123-139.

Conde Pazos, Miguel, «La embajada turca en Madrid y el envío de Alegreto de Allegretti a Constantinopla (1649-1650)», Libros de la Corte, 3 (Madrid, 2011b): 10-17.

D’Atri, Stefano, «Per Conservare la Città Tributtaria et Divota: Ragusa (Dubrovnik) and the 1590-91 Crisis», Dubrovnik Annals, 14 (Dubrovnik, 2010): 71-98.

Dahlgren, Stellan, «Russian archival sources on the Russian-Swedish negotiations in 1655-1657», en Michail S. Mejer, Russkaja i ukrainskaja diplomatija $v$ meždunarodnych otnošenijach v Evrope serediny XVII v., Moscú, Russian Academy of Science, 2007: 50-137.

Deanović, Mirko, «Frano Dživa Gundulića i Njegov Put u Moskvu 1655. g.», Starine (JAZU), 41 (Zagreb, 1948): 7-59.

Floristan Imízcoz, José M., Fuentes para la política oriental de los Austria, León, Universidad de León, 1988.

Frost, Robert, After the Deluge: Poland-Lithuania and the Second Northern War, 1655-1660, Cambridge, University Press, 2003.

González Cuerva, Rubén, «El Turco en las puertas: política oriental de Felipe III», en José Martínez Millán y Miguel Ángel Visceglia, La monarquía de Felipe III: Los Reinos, Madrid, Mapfre, 2008, vol. 4: 1447-1471.

González Cuerva, Rubén, «La fazione spagnola presso la corte imperiale e i nunzi (1628-1635)», QFIAB, 98 (Roma, 2018): 72-87.

Gualdo Priorato, Galeazzo, Historia Di Leopoldo Cesare: nella quale si narrano le Guerre..., Viena, Battista Hacque, 1669, vol. I.

Harris, Richard, Dubrovnik. A History, Londres, SAQI, 2006.

Hölbert, Lothar, «El Emperador, el Imperio y España bajo el reinado de Fernando III», en José Martínez Millán, Rubén González Cuerva y Manuel Rivero Rodríguez 
(dirs.), La Corte de Felipe IV (1621-1665): reconfiguración de la Monarquía católica, Madrid, Polifemo, 2018, tomo IV, vol. 1: 211-258.

Jasienica, Pawel, Calamity of the Realm. The Commonwalth of both nations II, Miami, American Institute of Polish Culture, 1992.

Konrádová, Monika y Smišek, Rostislav, «The Illusion of Power or Relentless Reality? Ceremonial and Ritual Practices at the Court of Moscow in the Middle of the 17th Century through the Eyes of the Imperial Diplomats», Theatrum historiae, 19 (Pardubice, 2016): 45-73.

Kostić, Veselin, «Ragusa and the Spanish Armada», Balcanica, 3/13 (Belgrado, 1972): 195-235.

Labrador Arroyo, Félix, «La organización de la casa y el séquito de la reina de Hungría en su Jornada al Imperio en 1629-1630», en José Martínez Millán y Rubén González Cuerva (coords.), La dinastía de los Austria: las relaciones entre la Monarquía Católica y el Imperio, Madrid, Polifemo, 2011, vol. 2: 801-836.

Lume, Lucio, L'archivio storico di Dubrovnik. Con repertorio di documenti sulle relazioni della republicca di Ragusa con le cittá marchigiane, Roma, Quaderni della rassegna degli archivi di stato, 1977.

Marek, Pawel, «La red clientelar española en la corte imperial en la época de Olivares», en José Martínez Millán, Rubén González Cuerva y Manuel Rivero Rodríguez (dirs.), La Corte de Felipe IV (1621-1665): reconfiguración de la Monarquía católica, Madrid, Polifemo, 2018, vol. 1: 117-210.

Mejer, Michail S., Russkaja i ukrainskaja diplomatija v meždunarodnych otnošenijach v Evrope serediny XVII v., Moscú, Russian Academy of Science, 2007.

Miović-Perić, Vesna, «Dragomans of the Dubrovnik Republic: their Training and Career», Dubrovnik Annals, 5 (Dubrovnik, 2001): 81-94.

Molnár, Antal, «Missionari Benedettini Ragusei nell’Ungheria Ottomana (15871612)», Rivista di Studi Ungheresi, 11 (Roma, 2012): 47-68.

Negredo del Cerro, Fernando, «Un episodio español en la Guerra de los Treinta Años: la embajada del marqués de Caldreita al Sacro Imperio y el acercamiento al Elector Sajón (1629-1631)», Hispania, 25/251 (Madrid, 2015): 669-693.

Novo Zaballos, José R., Las casas reales en tiempos de Carlos II. La casa de la reina Mariana de Austria, tesis doctoral, Universidad Autónoma de Madrid, 2016.

Petitjean, Johann, «On his Holiness' Secret Service: How Ragusa Became an Intelligence Agency after Lepanto», en Gábor Kárman y Radu G. Păun, European and the "Ottoman World», Exchanges and Conflicts, Estambul, The Isis Press, 2013: 83-106.

Polić, Bobić M., Entre la cruz y la media luna: avisos de Ragusa a la corte del rey de España sobre los turcos en el siglo XVI, Zagreb, Naklada Ljevak, 2000.

Pribram, Alfred F., «Österreichische Vermittelungs-Politik im Polnisch-Russischen Kriege, 1654-1660», Archiv für österreichische Geschichte, 72/2 (Viena, 1889): 415-480.

Przezdziecki, Renaud, «Embajadas españolas», Boletín de la Real Academia de la Historia, 122/2 (Madrid, 1948): 509-593. 
Quiles Albero, David, «Las relaciones hispano-venecianas en el contexto de la Guerra de Candia (1645-1669)», Chronica nova: Revista de historia moderna de la Universidad de Granada, 44 (Granada, 2018): 381-406.

Schwarcz, Iskra, «Die diplomatischen Beziehungen Österreich - Russland in der zweiten Hälfte des XVII. Jahrhunderts», Mitteilungen des Österreichischen Staatsarchivs, 50 (Innsbruck, 2003): 29-42.

Skowron, Ryszard, Pax i Mars. Polsko-hiszpańskie relacje polityczne $w$ latach 16321648, Cracovia, Universidad Jagellonica, 2013.

Skowron, Ryszard, «Las levas de polacos para los ejércitos españoles en la época de la guerra de los Treinta Años», en Enrique García Hernán y Ryszard Skowron (eds.), From Ireland to Poland, Northern Europe, Spain and the early Modern World, Valencia, Albatros, 2015: 19-37.

Sola, Emilio, «Ragusa y los espías, clásicos mínimos», Archivo de la Frontera, 2009, disponible en: http://www.archivodelafrontera.com/clasicos-minimos/ragusa-ylos-espias/ Fecha de consulta: 07/11/2021.

Sotirović, Vladislav, «The Idea of Pan-Slavic Ethnolinguistic Kinship and Reciprocity in Dalmatia and Croatia, 1477-1683», Politikos mokslu almanachas, 15 (Vilna, 2014): $175-187$.

Šundrica, Zdravko, «Poisons and Poisoning in the Republic of Dubrovnik», Dubrovnik Annals, 4 (Dubrovnik, 2000): 7-79.

Tenenti, Alberto y Tenenti, Branislava, Il Prezzo del Rischio, L'assicurazione mediterránea vista da Ragusa (1563-1591), Roma, Jouvence, 1985.

Tercero Casado, Luis, «La jornada de la reina Mariana de Austria a España: divergencias políticas y tensión protocolar en el seno de la Casa de Austria (1648-1649)», Hispania, 71/239 (Madrid, 2011): 639-664.

Valladares Ramírez, Rafael, La rebelión de Portugal: guerra, conflicto y poderes en la Monarquía Hispánica (1640-1680), Valladolid, Junta de Castilla y León, 1998.

Van Gelder, Maartje y Krstić, Tijana, «Introduction: Cross-Confessional Diplomacy and Diplomatic Intermediaries in the Early Modern Mediterranean», Journal of Early Modern History, 19 (York, 2015): 93-105.

Vargas-Hidalgo, Rafael, Guerra y diplomacia en el Mediterráneo: correspondencia inédita de Felipe II con Andrea Doria y Juan Andrea Doria, Madrid, Crónicas y memorias, 2003.

Vermeir, René, En estado de guerra. Felipe IV y Flandes, 1629-1648, Córdoba, Universidad de Córdoba, 2006.

Villari, Luigi, The Republic of Ragusa. An episode of the Turkish Conquest, Londres, J.M. Dent, 1904.

Zlatar, Zdenko, Between the Double Eagle and the Crecent. The Republic of Dubrovnik and the Origins of the Eastern Question, New York, Columbia University Press, 1992a.

Zlatar, Zdenko, Our Kingdom Come. The Counter-Reformation, the Republic of Dubrovnik and the Liberation of the Balkan Slavs, New York, Columbia University Press, $1992 b$. 